\title{
Pituitary and ovarian responses of post-partum acyclic beef cows to continuous long-term GnRH and GnRH agonist treatment
}

\author{
M. J. D’Occhio, D. R. Gifford*, C. R. Earl†, T. Weatherly and \\ W. von Rechenberg $\ddagger$
}

CSIRO, Division of Tropical Animal Production, Tropical Cattle Research Centre, P.O. Box 5545, Rockhampton Mail Centre, Queensland 4702, Australia; *South Australian Department of Agriculture, Turretfield Research Centre, Rosedale, South Australia 5350, Australia; $\dagger$ South Australian Department of Agriculture, Struan Research Centre, Naracoorte, South Australia 5271, Australia; and $\ddagger$ Hoechst AG, D-6230 Frankfurt, Federal Republic of Germany

\begin{abstract}
Summary. Post-partum acyclic beef cows received continuous long-term treatment with GnRH ( 200 or $400 \mathrm{ng} / \mathrm{kg}$ body wt/h) or the GnRH agonist buserelin $(5.5$ or $11 \mathrm{ng} / \mathrm{kg}$ body wt/h) using s.c. osmotic minipumps which were designed to remain active for 28 days. All treatments increased circulating $\mathrm{LH}$ concentrations whereas FSH remained unchanged. Ovulation and corpus luteum (CL) formation as judged by progesterone concentrations $\geqslant 1 \mathrm{ng} / \mathrm{ml}$ occurred in $0 / 5$ control, 4/5 $200 \mathrm{ng} \mathrm{GnRH}, 4 / 4$ $400 \mathrm{ng}$ GnRH, 4/5 5.5 ng buserelin and $3 / 511 \mathrm{ng}$ buserelin cows. The outstanding features of the progesterone profiles were the synchrony, both within and across groups, in values $\geqslant 1 \mathrm{ng} / \mathrm{ml}$ around Day 6 , and the fact that most CL were short-lived (4-6 days). Only 3 cows, one each from the $400 \mathrm{ng} \mathrm{GnRH}, 5 \cdot 5 \mathrm{ng}$ buserelin and $11 \mathrm{ng}$ buserelin groups, showed evidence of extended CL function. Cows failed to show a second ovulation which was anticipated around Day 10 and this could have been due to insufficient FSH to stimulate early follicular development, or the absence of an endogenously driven $\mathrm{LH}$ surge. The highest $\mathrm{LH}$ concentrations for the respective groups were observed on Days 2 and 6 and by Day $10 \mathrm{LH}$ was declining, although concentrations did remain higher than in controls up to Day 20. The fact that LH remained elevated in treated cows, but CL were nevertheless short-lived, suggested that endogenous LH secretion in post-partum cows following a GnRH-induced ovulation is not limiting to $\mathrm{CL}$ function, and that other factors cause early demise of the first CL. The doses of GnRH used were not directly limiting to CL function since in a second trial extended CL were observed when GnRH was preceded by progesterone.
\end{abstract}

Keywords: cow; post partum; continuous GnRH; ovary

\section{Introduction}

Exogenous gonadotrophin-releasing hormone $(\mathrm{GnRH})$ can be used to promote ovarian activity and ovulation in acyclic post-partum cows. In initial studies GnRH was administered in pulsatile regimens which were designed to mimic endogenous patterns of LH secretion (Riley et al., 1981; Walters et al., 1982). However, more recent work has shown that ovulation can also be induced in post-partum cows by continuous low-dose infusion of GnRH over 2-5 days (Capel et al., 1984; Jagger et al., 1987; Peters et al., 1987) or bolus injection (Smith et al., 1987). Corpora lutea (CL) arising from GnRH-induced ovulations post partum tend to have a short life-span which can be 
extended if GnRH is preceded by a period of progesterone treatment (Troxel \& Kesler, 1984; Rutter et al., 1985; Peters et al., 1987; Smith et al., 1987). The first ovulation post partum under normal conditions also usually produces a short-lived CL (Manns et al., 1983) and the suggestion has been made, although the mechanism remains unclear, that progesterone produced by the first CL post partum is a prerequisite for a normal CL to develop in the ensuing cycle (Rutter et al., 1985).

The requirement of progesterone pretreatment detracts from practical development of GnRH therapies in post-partum beef cows. An alternative approach was suggested by the study of Webb et al. (1977) in which GnRH was given as two injections around 10 days apart. Cows which responded to the first injection with a short-lived CL showed normal CL function after the second injection. This GnRH schedule essentially achieved the same objective as progesterone pretreatment by utilizing endogenous progesterone priming.

GnRH therapies would become particularly attractive if GnRH could be administered as a single slow-release formulation. The present study therefore examined whether sustained CL function can be achieved with continuous long-term $\mathrm{GnRH}$ therapy. It was considered that chronic GnRH treatment was unlikely to extend the life-span of the first induced CL, but that it might induce a second ovulation with a normal CL. Post-partum acyclic cows received continuous GnRH from subcutaneous osmotic minipumps designed to remain active for 28 days and observations were made on pituitary and ovarian responses.

\section{Materials and Methods}

Animals. Shorthorn cows ranging from 5 to 8 years of age ( $400-450 \mathrm{~kg}$ body weight) and which were in at least their third post-partum period were used in the first trial. Cows calved during early winter and were maintained under field conditions with their calves in a temperate environment. A group of $2 \frac{1}{2}$-year-old post-partum Hereford heifers that were similarly managed were used in a second trial to examine the effects of progesterone pretreatment on responses to continuous long-term GnRH.

Experimental procedures. The treatment groups and days post partum (mean \pm s.e.m.) for cows in the first trial were as follows: control $(\mathrm{N}=5), 16.6 \pm 1.7 ; 200 \mathrm{ng} \mathrm{GnRH} / \mathrm{kg}$ body $\mathrm{wt} / \mathrm{h}(\mathrm{N}=5), 17.6 \pm 1.8 ; 400 \mathrm{ng} \mathrm{GnRH}$ $(\mathrm{N}=4), 18 \cdot 0 \pm 1 \cdot 6 ; 5 \cdot 5 \mathrm{ng}$ buserelin $(\mathrm{N}=5) ; 17 \cdot 0 \pm 1 \cdot 7 ; 11 \mathrm{ng}$ buserelin $(\mathrm{N}=5), 16 \cdot 8 \pm 1 \cdot 9$. Native GnRH and the GnRH agonist, buserelin ([D-Ser $(\mathrm{tBu})^{6}$, Pro $\left.\left.^{9} \mathrm{NEt}\right] \mathrm{GnRH}\right)$, were delivered continuously using osmotic minipumps (2ML4, Alza Corporation, Palo Alto, CA, USA) which were placed subcutaneously in the lower neck under aseptic conditions and local lignocaine anaesthesia. Cows received one or two pumps depending on whether they were in the low- or high-dose treatment groups, both for GnRH and buserelin. Dose rates were calculated for a body weight of $450 \mathrm{~kg}$. Cows were bled at $30 \mathrm{~min}$ intervals for $4 \mathrm{~h}$ by jugular venepuncture on the day before treatment (Day -1$)$ and again on Days 2, 6, 10 and 20 of treatment. Additional single blood samples were taken on Days 4, 8, 12,16 and 28 at which time the pumps were removed. Heparinized blood samples were kept on ice and the plasmas obtained after centrifugation were stored at $-20^{\circ} \mathrm{C}$ until required for hormone assay.

To determine whether the doses of $\mathrm{GnRH}$ used in the first trial might be limiting to $\mathrm{CL}$ function primiparous heifers received 200 or $400 \mathrm{ng} \mathrm{GnRH}$, or $5 \mathrm{ng}$ of the $\mathrm{GnRH}$ agonist, D-Trp ${ }^{6} \mathrm{GnRH}$, with or without 7 days pretreatment with progesterone using intravaginal devices (PRID, Bomac Laboratories, Sydney, Australia). Days post partum at the start of $\mathrm{GnRH}$ treatment were $(\mathrm{N}=5 /$ group): control, $41 \cdot 3 \pm 3 \cdot 8 ; 200 \mathrm{ng} \mathrm{GnRH}, 41 \cdot 1 \pm 3 \cdot 8$; progesterone + $200 \mathrm{ng}$ GnRH, $41 \cdot 8 \pm 3 \cdot 2 ; 400 \mathrm{ng}$ GnRH, $42 \cdot 1 \pm 3 \cdot 5 ;$ progesterone $+400 \mathrm{ng}$ GnRH, 41.3 $\pm 2 \cdot 6 ; 5 \mathrm{ng}$ D-Trp ${ }^{6}$, $39 \cdot 7 \pm 3 \cdot 5$; progesterone $+5 \mathrm{ng}$ D-Trp ${ }^{6}, 42 \cdot 2 \pm 3 \cdot 7$. Osmotic minipumps were used as described above and blood samples were taken on Days $-7,-1,0,6,11,14,18,22$ and 29 relative to the start of $\mathrm{GnRH}$ treatment.

Hormone assays. Plasma concentrations of LH and FSH were determined by double-antibody radioimmunoassays (D'Occhio et al., 1986) only in serial samples collected in the first trial. An extraction single-antibody radioimmunoassay (D'Occhio et al., 1988) was used to measure plasma progesterone concentrations in both trials. Progesterone concentrations $\geqslant 1 \mathrm{ng} / \mathrm{ml}$ were taken as being indicative of ovulation and formation of active CL. Intraand inter-assay coefficients of variations for all assays were $<10 \%$ based on duplicate samples. Sensitivities were $4 \mathrm{ng}$ $\mathrm{FSH} / \mathrm{ml}, 0 \cdot 2 \mathrm{ng} \mathrm{LH} / \mathrm{ml}$ and $0 \cdot 1 \mathrm{ng}$ progesterone $/ \mathrm{ml}$.

Statistical analyses. Data for LH and FSH in the first trial were transformed to $\log _{10}$ before testing for treatment effects using analysis of variance procedures. The 5 days were analysed both separately and together. Using Day -1 concentrations as a covariate (log scale) in analysis of Days 2, 6, 10 and 20 did not influence the analyses. The data (log scale) were also orthogonally transformed to give a mean, linear, quadratic and cubic effect for each cow and these were analysed for treatment differences, firstly with all 5 days for the shape of the response over time, and then 
with the 4 treatment days. Increases in LH were determined to be a pulse if the rise was $>40 \%$ above basal concentrations and was followed by a series of points that showed a progressive decline. Basal LH concentrations were calculated from points not associated with the apex or descending portions of pulses.

\section{Results}

\section{Luteinizing hormone}

Plasma LH concentrations for cows in the first trial were uniformly low on Day -1 and there were no differences $(P>0.05)$ between groups; however, pulses of LH were observed in some cows (Table 1). LH values in control cows remained constant during the study whereas for all treated groups LH increased sharply up to Days 2-6 and then decreased, still being slightly, but significantly $(P<0.01)$, above pretreatment concentrations on Day 20 . Treated cows consequently had higher $(P<0.01)$ plasma LH concentrations than did controls on Days 2, 6, 10 and 20. Increased LH concentrations during treatment resulted primarily from elevated basal concentrations rather than increased pulsatile secretion. However, pulses of LH were observed at various times during treatment, particularly in cows receiving $200 \mathrm{ng}$ GnRH (Table 1). Differences in LH between treated groups were observed only on Day 6 when concentrations were higher $(P<0.01)$ for cows receiving $200 \mathrm{ng}$ GnRH. However, when Days -1 to 20 were analysed together, the treated groups were not different in the mean, linear, or quadratic or cubic effects. On the $\log _{10}$ scale the 4 treatments had the same significant quadratic and cubic components over the 20 -day period but the controls did not change.

Table 1. Plasma LH concentrations* in post-partum cows receiving continuous GnRH or buserelin

\begin{tabular}{lcccccc}
\hline \multirow{2}{*}{$\begin{array}{l}\text { Treatment } \\
(/ \mathrm{kg} \text { body wt/h) }\end{array}$} & $\begin{array}{c}\text { No. of } \\
\text { cows }\end{array}$ & Day $-\mathrm{I}$ & Day 2 & Day 6 & Day 10 & Day 20 \\
\cline { 3 - 7 } Control & 5 & $0.33 \pm 0.03(1)$ & $0.31 \pm 0.04(0)$ & $0.32 \pm 0.04(0)$ & $0.32 \pm 0.03(0)$ & $0.38 \pm 0.04(1)$ \\
& 5 & $0.43 \pm 0.03(2)$ & $0.80 \pm 0.13(2)$ & $0.98 \pm 0.14(4)$ & $0.69 \pm 0.07(4)$ & $0.63 \pm 0.10(5)$ \\
$400 \mathrm{ng}$ GnRH GnRH & 4 & $0.35 \pm 0.06(1)$ & $0.72 \pm 0.09(1)$ & $0.59 \pm 0.09(1)$ & $0.63 \pm 0.08(1)$ & $0.48 \pm 0.10(2)$ \\
5.5 ng buserelin & 5 & $0.33 \pm 0.04(0)$ & $0.61 \pm 0.08(1)$ & $0.57 \pm 0.06(0)$ & $0.56 \pm 0.08(1)$ & $0.45 \pm 0.03(0)$ \\
Il ng buserelin & 5 & $0.34 \pm 0.02(0)$ & $0.67 \pm 0.06(0)$ & $0.54 \pm 0.03(0)$ & $0.53 \pm 0.03(0)$ & $0.50 \pm 0.04(0)$
\end{tabular}

Values are mean \pm s.e.m. of individual 4-h means; numbers in parentheses indicate no. of cows with pulsatile $\mathrm{LH}$ secretion.

*At each sampling period cows were bled at 30 -min intervals for $4 \mathrm{~h}$.

\section{Follicle-stimulating hormone}

In contrast to $\mathrm{LH}$, circulating $\mathrm{FSH}$ was not increased during treatment with GnRH or buserelin (Table 2). FSH concentrations therefore remained constant during the study in control and treated cows. There was no evidence of pulsatile FSH secretion, before or during treatment.

\section{Progesterone}

None of the control cows in the first trial showed progesterone concentrations $\geqslant 1 \mathrm{ng} / \mathrm{ml}$ whereas $15 / 19$ treated cows had elevated progesterone values. The outstanding features of the 
Table 2. Plasma FSH concentrations in post-partum cows receiving continuous GnRH or buserelin

\begin{tabular}{|c|c|c|c|c|c|c|}
\hline \multirow{2}{*}{$\begin{array}{l}\text { Treatment } \\
(/ \mathrm{kg} \text { body } \mathrm{wt} / \mathrm{h})\end{array}$} & \multirow{2}{*}{$\begin{array}{l}\text { No. of } \\
\text { cows }\end{array}$} & \multicolumn{5}{|c|}{ FSH conc. (ng/ml) } \\
\hline & & Day -1 & Day 2 & Day 6 & Day 10 & Day 20 \\
\hline Control & 5 & $12 \cdot 7 \pm 1 \cdot 7$ & $11 \cdot 7 \pm 1 \cdot 8$ & $11 \cdot 6 \pm 1 \cdot 4$ & $12 \cdot 2 \pm 1 \cdot 1$ & $11 \cdot 3 \pm 1 \cdot 1$ \\
\hline 200 ng GnRH & 5 & $15 \cdot 4 \pm 3 \cdot 6$ & $16.7 \pm 3.4$ & $13 \cdot 3 \pm 2 \cdot 6$ & $14 \cdot 8 \pm 3 \cdot 5$ & $16 \cdot 1 \pm 2 \cdot 9$ \\
\hline 400 ng GnRH & 4 & $13 \cdot 5 \pm 2 \cdot 2$ & $14 \cdot 6 \pm 1 \cdot 5$ & $13 \cdot 4 \pm 2 \cdot 4$ & $13 \cdot 7 \pm 1 \cdot 8$ & $14 \cdot 4 \pm 2 \cdot 7$ \\
\hline $5 \cdot 5 \mathrm{ng}$ buserelin & 5 & $12 \cdot 3 \pm 1 \cdot 5$ & $14 \cdot 1 \pm 1 \cdot 6$ & $13 \cdot 9 \pm 2 \cdot 1$ & $13 \cdot 1 \pm 1 \cdot 3$ & $14.4 \pm 1 \cdot 0$ \\
\hline $11 \mathrm{ng}$ buserelin & 5 & $14 \cdot 8 \pm 2 \cdot 6$ & $14 \cdot 1 \pm 1 \cdot 7$ & $13 \cdot 1 \pm 2 \cdot 1$ & $12 \cdot 7 \pm 2 \cdot 0$ & $14 \cdot 8 \pm 2 \cdot 0$ \\
\hline
\end{tabular}

At each sampling period cows were bled at 30 -min intervals for $4 \mathrm{~h}$ and the results are presented as the mean \pm s.e.m. of individual 4-h means.

progesterone profiles in cows receiving GnRH or buserelin were the synchrony, both within and across groups, in appearance of elevated progesterone around Day 6, and the fact that most $\mathrm{CL}$ appeared to be short-lived (Table 3). Only 3 cows, one from each of the $400 \mathrm{ng}$ GnRH, $5 \cdot 5 \mathrm{ng}$ buserelin, and $11.0 \mathrm{ng}$ buserelin groups, showed evidence of extended CL function. Two of these cows continued to have elevated progesterone on Day 28 but it was not possible to conclude whether this was due to persistence of the first CL, or the result of a second ovulation between Days 20 and 28.

Table 3. Ovarian responses in post-partum cows receiving continuous

$\mathrm{GnRH}$ or buserelin

\begin{tabular}{lcccc}
\hline \multirow{2}{*}{$\begin{array}{l}\text { Treatment } \\
\text { (/kg body wt/h) }\end{array}$} & $\begin{array}{c}\text { No. of } \\
\text { cows }\end{array}$ & $\begin{array}{c}\text { Progesterone } \\
\geqslant 1 \mathrm{ng} / \mathrm{ml}\end{array}$ & Short-lived & Extended \\
\cline { 4 - 5 } Control & 5 & 0 & 0 & 0 \\
200 ng GnRH & 5 & 4 & 4 & 0 \\
400 ng GnRH & 4 & 4 & 3 & 1 \\
$5 \cdot 5$ ng buserelin & 5 & 4 & 3 & 1 \\
11 ng buserelin & 5 & 3 & 2 & 1 \\
\hline
\end{tabular}

In the second trial pretreatment with progesterone extended the life-span of CL induced by GnRH and D-Trp ${ }^{6}$ (Fig. 1). This indicated that the doses of GnRH used in the first trial were not directly limiting to CL function. The short life-span CL in heifers that received GnRH or D-Trp ${ }^{6}$ alone were similar to those observed in cows in the first trial.

\section{Discussion}

The present study sought to determine whether continuous long-term GnRH treatment could be used to induce ovulation with normal $\mathrm{CL}$ function in the post-partum cow. In the first trial the majority of cows receiving GnRH or buserelin ovulated, as judged by increases in plasma progesterone, but CL were short-lived. Plasma LH concentrations were increased for at least 20 days yet only 5/14 cows with elevated progesterone on Days 6 and 8 continued to have high progesterone on Day 10. Chronically increased LH secretion therefore did not sustain the activity of CL associated with the first induced ovulation. It has been concluded from previous studies that short-lived CL do not have reduced LH receptor concentrations (Rutter et al., 1985); however, it remained 
(a) Control

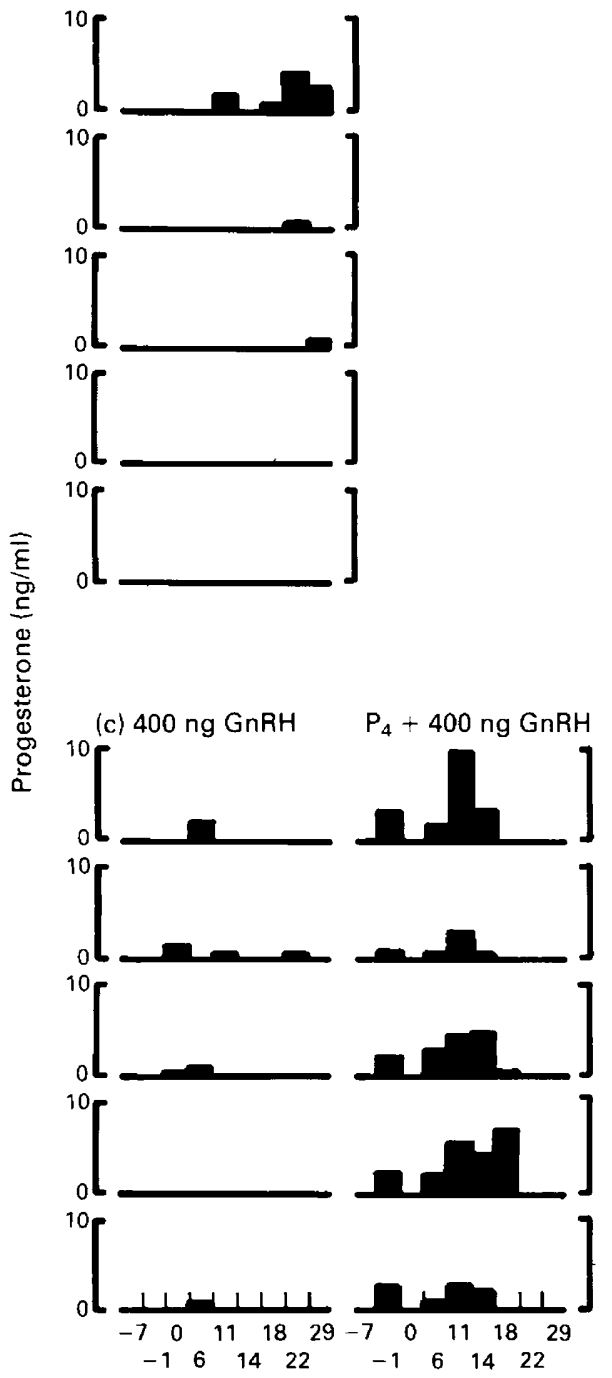

(b) $200 \mathrm{ng} \mathrm{GnRH}$

$\mathrm{P}_{4}+200 \mathrm{ng} \mathrm{GnRH}$
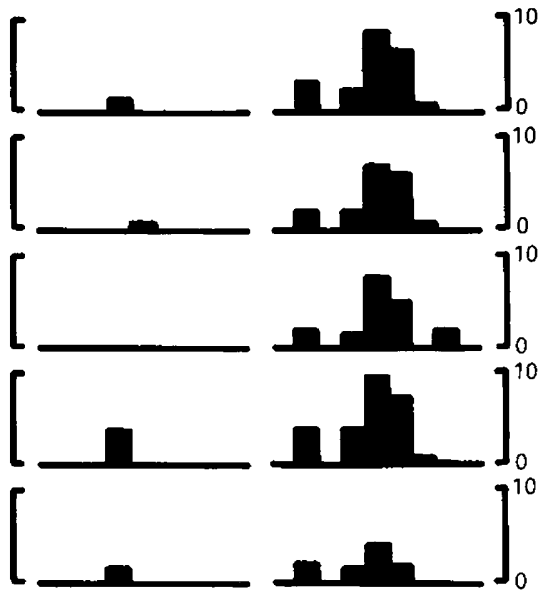

(d) $5 \mathrm{ng} \mathrm{D-Trp} 6$


Day of treatment

Fig. 1. Plasma progesterone profiles in (a) control post-partum heifers and post-partum heifers that received (b) $200 \mathrm{ng} \mathrm{GnRH} / \mathrm{kg}$ body wt/h or progesterone $+200 \mathrm{ng} \mathrm{GnRH} \mathrm{GnRH} / \mathrm{kg}$ body wt $/ \mathrm{h}$, (c) $400 \mathrm{ng} \mathrm{GnRH} / \mathrm{kg}$ body wt/h or progesterone $+400 \mathrm{ng} \mathrm{GnRH} / \mathrm{kg}$ body wt $/ \mathrm{h}$, (d) $5 \mathrm{ng}$ $\mathrm{D}-\operatorname{Trp}^{6} / \mathrm{kg}$ body $\mathrm{wt} / \mathrm{h}$ or progesterone $+5 \mathrm{ng} \mathrm{D}-\operatorname{Trp}^{6} / \mathrm{kg}$ body $\mathrm{wt} / \mathrm{h}$. Heifers received progesterone from Day -7 to Day -1 and continuous GnRH or D-Trp ${ }^{6}$ treatment was started on Day 0.

unclear whether endogenous LH secretion was sufficient to sustain CL function. In the first trial the highest LH concentrations were observed in cows receiving $200 \mathrm{ng}$ GnRH and yet none of these cows had an extended luteal phase. Also, the 3 cows that showed evidence of continued progesterone secretion did not necessarily have the highest $\mathrm{LH}$ for their respective groups. It would appear, therefore, that endogenous LH secretion in post-partum cows following a GnRH-induced preovulatory LH surge is not limiting to CL function, and that other factors cause early demise of the first GnRH-induced CL post partum. 
Short life-span CL were reported to have increased numbers of large luteal cells (Manns et al., 1983; Rutter et al., 1985). These cells contain prostaglandin receptors and it is thought that under normal conditions an increase in large cells sensitizes the CL to prostaglandin (Fitz et al., 1982). Small and large luteal cells are initially derived from theca and granulosa cells, respectively, and it has been suggested that a proportion of small cells may later differentiate into large cells (Niswender et al., 1985; Hansel et al., 1987; O'Shea, 1987). This secondary differentiation could occur prematurely in short-lived CL leading to earlier sensitization to prostaglandin (Rutter $e t$ al., 1985). The hormonal requirements for normal differentiation of luteal tissue are unknown but a balance of LH and FSH might be necessary. FSH remained unchanged in the present study and both increased (Walters et al., 1982; Jagger et al., 1987) and decreased (Peters et al., 1985, 1987) FSH secretion in response to GnRH has been reported. Williams et al. (1984) suggested that progesterone acts on the hypothalamus and pituitary to normalize LH and FSH secretion ensuring proper follicular maturation. If this proves to be the mechanism whereby pre-exposure to progesterone facilitates normal CL development, then FSH responses to GnR H might be of particular significance. A role for FSH in the final stages of follicular development was suggested by the failure to ovulate of GnRH-treated seasonally anoestrous ewes in which FSH was suppressed with bovine follicular fluid (McLeod \& McNeilly, 1987). However, it was concluded from another study in ewes that facilitation of normal CL development by progesterone pretreatment was not related to FSH secretion (McLeod \& Haresign, 1987). Rather, progesterone priming appeared to influence gonadotrophin binding and steroidogenesis in follicles (Hunter et al., 1986).

In the first trial only $3 / 15$ cows that had elevated progesterone also showed evidence of sustained CL function. It was not possible to conclude whether increased progesterone in 2 cows on Day 28 reflected continued activity of the first $\mathrm{CL}$, or resulted from a second ovulation between Days 20 and 28. Webb et al. (1977) reported that normal CL function was induced by the second of two injections of GnRH given $\sim 10$ days apart. On Day 10 in the first trial progesterone had declined in 9/14 cows which showed increased progesterone on Days 6 and 8 , but none of these cows showed evidence of a second ovulation. Similarly, no heifers receiving GnRH or D-Trp ${ }^{6}$ alone in the second trial showed a second ovulation. Progesterone inhibits follicular maturation by suppressing LH secretion rather than by direct actions on the ovary. Thus, pulsatile exogenous GnRH over 3-5 days can promote follicular growth and development in the presence of elevated progesterone (Glencross, 1987). If progesterone declines, the follicles can proceed to ovulation (Glencross, 1987). This sequence of events apparently failed to occur in the present study, even though LH remained elevated at Day 10 in the first trial. However, FSH was unchanged and it is therefore possible that FSH concentrations were inadequate to stimulate early follicles to a point where they could respond to $\mathrm{LH}$. Oestradiol-17 $\beta$ secretion would consequently have been insufficient to trigger an endogenous LH surge. Additional studies detailing patterns of secretion of oestradiol-17 $\beta$, LH and FSH in post-partum cows receiving continuous long-term GnRH are required to elucidate the factors which in the present study caused failure of a second ovulation. In some cows progesterone remained elevated for only 2-4 days which could be considered insufficient time to achieve progesterone priming. However, in ewes, 2 days' exposure to progesterone was adequate for normal development of subsequent CL (McLeod \& Haresign, 1984). In the second trial heifers that showed extended CL function after progesterone pretreatment also apparently failed to undergo a second ovulation.

Continuous GnRH has been used to induce ovulation in seasonally (Wright et al., 1983; McLeod et al., 1983; Williams et al., 1984) and post-partum (Williams et al., 1984) acyclic ewes. Normal CL function in ewes requires progesterone pretreatment (McLeod et al., 1982; Hunter et al., 1986) and the same requirement was confirmed for cows in the present study. In contrast, fertile ovulations and normal CL have been induced in seasonally (Hyland et al., 1985; Allen et al., 1987) and post-partum (Allen et al., 1987) acyclic mares with continuous GnRH in the absence of progesterone priming. Similar responses can be produced in post-partum acyclic sows with pulsatile GnRH (Cox \& Britt, 1982; Armstrong \& Britt, 1985). These species differences are consistent with 
results of other studies which indicate that normal CL function requires progesterone priming in cows and ewes, but not in sows and mares.

In conclusion, continuous long-term therapy with GnRH or GnRH agonists induced ovulation in acyclic post-partum beef cows and heifers but CL were short-lived and a second ovulation with normal CL anticipated around Day 10 of treatment did not occur. Failure of a second ovulation could have been due to insufficient FSH to stimulate early follicular development; this would have precluded events leading to an endogenous LH surge. The similarity in gonadotrophin and ovarian responses observed with $\mathrm{GnRH}$ agonists at doses 20-80 times lower than those of GnRH illustrate the potential of agonists as practical substitutes in $\mathrm{GnRH}$ therapies.

We thank Dr D. J. Bolt (USDA, Baltimore, MD, USA), Dr R. I. Cox (CSIRO, Division of Animal Production, Prospect, NSW, Australia) and the NIADDK for generous supplies of radioimmunoassay materials; Dr T. E. Trigg (Peptide Technology Limited, Dee Why, NSW, Australia) for providing native GnRH and D-Trp ${ }^{6} \mathrm{GnRH}$; Ms L. Broadhurst, Ms S. Coombe, Mr G. J. Haines, Mr R. J. Lampe, Mr A. Niesh, Mr S. Sowerbutts and Mr R. Wicke for expert technical assistance; Dr R. M. Seebeck and Ms A. Bourne for advice on statistical analyses; Ms T. M. Bennett for typing the manuscript; and $\mathrm{Mr} \mathrm{B}$. Milligan and $\mathrm{Mr} \mathrm{R}$. Norton for making available facilities at 'Bolivar' and for management of the animals. The study was supported in part by the Australian Meat and Livestock Research and Development Corporation.

\section{References}

Allen, W.R., Sanderson, M.W., Greenwood, R.E.S., Ellis, D.R., Crowhurst, J.S., Simpson, D.J. \& Rossdale, P.D. (1987) Induction of ovulation in anoestrous mares with a slow-release implant of a GnRH analogue (ICI 118 630). J. Reprod. Fert., Suppl. 35, $469-478$.

Armstrong, J.D. \& Britt, J.H. (1985) Pulsatile administration of gonadotropin-releasing hormone to anestrous sows: endocrine changes associated with GnRH-induced and spontaneous estrus. Biol. Reprod. 33, 375-380.

Capel, J.P., Peters, A.R. \& Lamming, G.E. (1984) Pulsatile vs continuous infusion of $\mathrm{GnRH}$ to induce $\mathrm{LH}$ release in the post-partum beef cow. Proc. 10th Int. Congr. Anim. Reprod. \& A.I., Urbana, vol. 2, 6, Abstr.

Cox, N.M. \& Britt, J.H. (1982) Pulsatile administration of gonadotropin releasing hormone to lactating sows: endocrine changes associated with induction of fertile estrus. Bial. Reprod. 27, 1126-1137.

D'Occhio, M.J., Gifford, D.R., Weatherly, T. \& Setchell, B.P. (1986) Evidence of gonadal steroid-independent changes in activity of the central LH-releasing hormone pulse generator in developing bull calves. $J$. Endocr. 111, 67-73.

D'Occhio, M.J., Gifford, D.R., Hoskinson, R.M., Weatherly, T. \& Setchell, B.P. (1988) Gonadotrophin secretion and ovarian responses in prepubertal heifers actively immunized against androstenedione and oestradiol-17ß. J. Reprod. Fert.83, 159-168.

Fitz, T.A., Mayan, M.H., Sawyer, H.R. \& Niswender, G.D. (1982) Characterization of two steroidogenic cell types in the ovine corpus luteum. Biol. Reprod. 27, 703-711.

Glencross, R.G. (1987) Effect of pulsatile infusion of gonadotrophin-releasing hormone on plasma oestradiol-17 $\beta$ concentrations and follicular development during naturally and artificially maintained high levels of plasma progesterone in heifers. $J$. Endocr. 112, 77-85.

Hansel, W., Alila, H.W., Dowd, J.P. \& Yang, X. (1987) Control of steroidogenesis in small and large bovine luteal cells. Aust. J. biol. Sci. 40, 331-347.

Hunter, M.G., Southee, J.A., McLeod, B.J. \& Haresign, W. (1986) Progesterone pretreatment has a direct effect on GnRH-induced preovulatory follicles to determine their ability to develop into normal corpora lutea in anoestrous ewes. J. Reprod. Fert. 76, 349-363.

Hyland, J.H., Wright, P.J., Clarke, I.J., Carson, R.S., Langsford, D.A. and Jeficott, L.B. (1985) Induction of ovulation in mares during seasonal anoestrus by infusion of gonadotrophin releasing hormone (GnRH). Proc. Aust. Soc. Reprod. Biol. 17, Abstr. 39.

Jagger, J.P., Peters, A.R. \& Lamming, G.E. (1987) Hormone responses to low-dose GnRH treatment in post-partum beef cows. J. Reprod. Fert. 80, 263-269.

Manns, J.G., Humphrey, W.D., Flood, P.F., Mapletoft, R.J., Rawlings, N. \& Cheng, K.W. (1983) Endocrine profiles and functional characteristics of corpora lutea following onset of postpartum ovarian activity in beef cows. Can. J. Anim. Sci. 63, 331-347.

McLeod, B.J. \& Haresign, W. (1984) Evidence that progesterone may influence subsequent luteal function in the ewe by modulating preovulatory follicle development. J. Reprod. Fert. 71, 381-386.

McLeod, B.J. \& Haresign, W. (1987) Plasma FSH concentrations in seasonally anoestrous ewes induced to ovulate with repeated injections or continuous infusion of GnRH. Anim. Reprod. Sci. 14, 53-63.

McLeod, B.J. \& McNeilly, A.S. (1987) Suppression of plasma FSH concentrations with bovine follicular fluid blocks ovulation in GnRH-treated seasonally anoestrous ewes. J. Reprod. Fert. 81, 187-194. 
McLeod, B.J., Haresign, W. \& Lamming, G.E. (1982) Response of seasonally anoestrous ewes to smalldose multiple injections of Gn-RH with and without progesterone pretreatment. J. Reprod. Fert. 65, 223-230.

McLeod, B.J., Haresign, W. \& Lamming, G.E. (1983) Induction of ovulation in seasonally anoestrous ewes by continuous infusion of low doses of Gn-RH. $J$. Reprod. Fert. 68, 489-495.

Niswender, G.D., Schwall, R.H., Fitz, T.A., Farin, C.E. \& Sawyer, H.R. (1985) Regulation of luteal function in domestic ruminants: new concepts. Recent Prog. Horm. Res. 41, 101-151.

O'Shea, J.D. (1987) Heterogeneous cell types in the corpus luteum of sheep, goats and cattle. J. Reprod. Fert., Suppl. 34, 71-85.

Peters, A.R., Pimentel, M.G. \& Lamming, G.E. (1985) Hormone responses to exogenous GnRH pulses in post-partum dairy cows. J. Reprod. Fert. 75, $557-565$.

Peters, A.R., Jagger, J.P. \& Lamming, G.E. (1987) Effects of $\mathrm{GnRH}$ administration in the prepubertal heifer and post-partum cow. Bovine Pract. 22, $102-103$.

Riley, G.M., Peters, A.R. \& Lamming, G.E. (1981) Induction of pulsatile $\mathrm{LH}$ release, FSH release and ovulation in post-partum acyclic beef cows by repeated small doses of Gn-RH. J. Reprod. Fert. 63, 559-565.

Rutter, L.M., Carruthers, T.D. \& Manns, J.G. (1985) The postpartum induced corpus luteum: functional differ- ences from that of cycling cows and the effects of progesterone pretreatment. Biol. Reprod. 33, 560-568.

Smith, V.G., Chenault, J.R., McAllister, J.F. \& Lauderdale, J.W. (1987) Response of postpartum beef cows to exogenous progestogens and gonadotropin releasing hormone. J. Anim. Sci. 64, 540-551.

Troxel, T.R. \& Kesler, D.J. (1984) The effect of progestin and GnRH treatments on ovarian function and reproductive hormone secretions of anestrous postpartum suckled beef cows. Theriogenology 21, 699-711.

Walters, D.L., Short, R.E., Convey, E.M., Staigmiller, R.B., Dunn, T.G. \& Kaltenbach, C.C. (1982) Pituitary and ovarian function in postpartum beef cows. III. Induction of estrus, ovulation and luteal function with intermittent small-dose injections of $\mathrm{GnRH}$. Biol. Reprod. 26, 655-662.

Webb, R., Lamming, G.E., Haynes, N.B., Hafs, H.D. \& Manns, J.G. (1977) Response of cyclic and postpartum suckled cows to injections of synthetic LH-RH. J. Reprod. Fert. 50, 203-210.

Williams, A.H., Wright, P.J. \& Clarke, I.J. (1984) GnRH in continuous low dose induces ovulation in both post-partum and seasonally anoestrous ewes. Proc. Aust. Soc. Reprod. Biol. 16, Abstr. 96.

Wright, P.J., Clarke, I.J. \& Findlay, J.K. (1983) The induction of fertile oestrus in seasonally anoestrous ewes using a continuous low dose administration of gonadotrophin releasing hormone. Aust. vet. J. 60 , 254-255.

Received 13 June 1988 